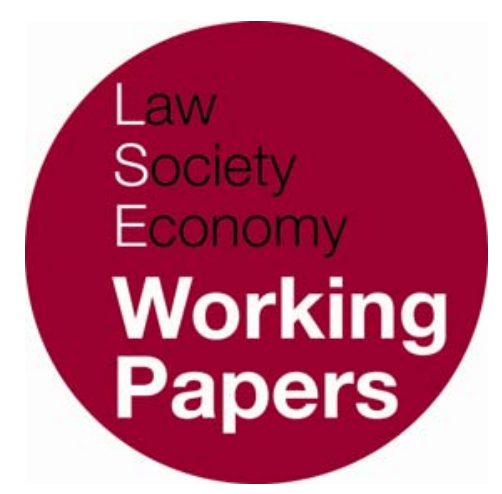

\title{
The Repatriation Debate and the Discourse of the Commons
}

\author{
Tatiana Flessas
}

LSE Law, Society and Economy Working Papers 10/2007 London School of Economics and Political Science Law Department

This paper can be downloaded without charge from LSE Law, Society and Economy Working Papers at: www.lse.ac.uk/collections/law/wps/wps.htm and the Social Science Research Network electronic library at: http://ssrn.comabstract=1021205.

(C) Tatiana Flessas. Users may download and/or print one copy to facilitate their private study or for non-commercial research. Users may not engage in further distribution of this material or use it for any profit-making activities or any other form of commercial gain. 


\title{
The Repatriation Debate and the Discourse of the Commons
}

\author{
Tatiana Flessas ${ }^{*}$
}

\begin{abstract}
What can the concept of 'the commons' lend to cultural property and heritage analysis? How can it be applied to these areas, if one looks beyond the protection of solely 'natural' resources such as land (although 'land', as a highly regulated substrate bearing a plethora of significations and values may itself no longer be considered a 'natural' resource)? The debates around property and culture are more usually understood by reference to 'cultural nationalism,' 'cultural internationalism' and the web of disciplines and resources that grow between these two traditional approaches, and yet, these resources leave many problems and issues in this field unresolved. The discourses that make up commons scholarship might serve to expand the tool box of cultural property discourse, in particular where the issues span the most personal and the most communal problems of all: human skeletons and repatriation claims. This essay argues that the very discourse of the commons itself is a strategy, a means of establishing and policing thresholds that in turn move according to strategies and desires of acquisition. In short, designating an object as located within 'the commons' is another way of justifying the appropriation of contested cultural property.
\end{abstract}

\section{INTRODUCTION}

In July 2000, UK Prime Minister Tony Blair met with Australian Prime Minister John Howard in London. On the agenda was the repatriation of Australian indigenous skeletons and associated objects currently held in UK institutions, and in particular, by the British Museum, the Natural History Museum, and other museums in the United Kingdom. When indigenous Australian groups requested the return of specific skeletons, 'the museums refused the requests on the grounds that return is prevented by legislation'. ${ }^{1}$ The Trustees of the British Museum had claimed that the terms on which they hold the collection in trust forbade them to accede positively to the demands of indigenous peoples. ${ }^{2}$ In July 2000 , the precise

\footnotetext{
* Law Dept., London School of Economics (t.flessas@1se.ac.uk)

1 Human Remains Report (2003), \$56, available at http://www.culture.gov.uk/Reference_library /Publications/archive_2003/wgur_report2003.htm.

2 The British Museum Act 1963 permits the Trustees to dispose of items in the collection under section 5 and section 9 of the Act. Neither section specifically allowed the repatriation of human remains.
} 
number and location of the indigenous Australian skeletons held by UK institutions was unknown. However, the requests to museums had begun to raise questions about the necessity, and possible structure, of a repatriation programme in the United Kingdom. After this meeting, the two Prime Ministers issued a statement declaring that "The Australian and British Governments agree to increase their efforts to repatriate human remains to Australian indigenous communities. In doing this, the Governments recognise the special connection that indigenous people have with ancestral remains, particularly where there are living descendants'. ${ }^{3}$ The statement committed both governments to a long-term cooperative effort, in consultation with indigenous organisations, to identify and repatriate indigenous human remains held in the UK.

This action brought the nascent repatriation debate in the United Kingdom into focus for museums and the other institutions that might be affected by changes in policy. The questions of how to conceptualize or categorize human bones, and how to consider, or justify, their appropriation (either by educational and scientific institutions or by cultural or genealogical claimants), raised issues of contested histories, colonialism, and the likelihood of being able to establish ongoing cultural connections across centuries and continents. Most importantly, the debate turned on the role and function of these bones within museums, and the potential clashes between the 'enlightenment' values espoused by most museums, which prioritize scientific and scholarly study and public access (with some limitations), and the values that turn on identity, personhood and community, and which might remove the bones from even limited appearances within the public domain. This 'clash' of values is inherent in any discussion that concerns itself with the ownership or allocation of human bones. Human bones evade ownership in any traditional sense: one the one hand, the question of property rights in the human body lacks a clear answer. ${ }^{4}$ On the other hand, the question is over-determined in legal theory: there are a plethora of conceptual and legal regimes that seek to analyze and regulate the function and meaning of 'Ownership' in this area.

The debate is especially problematic because of the fluid set of identities or identifications that human bones or skeletons can take in different institutions and during different political or historical eras. The plasticity of both the physical and the cultural resources to be administered lies at the core of cultural property disputes, and functions to destabilize many of the certainties otherwise guaranteed by law. For example, a skeleton may be an artefact, an ancestor, an object of scientific study, a political icon, or a religious relic. The skeleton found on the banks of the Columbia River in Washington State in 1996, and later named

${ }^{3}$ n 1 above, 2.

${ }^{4}$ Human Tissue Act 2004 Section 32, Prohibition of commercial dealings in human material for transplantation', but see \$32(9) which excludes 'gametes and embryos..., and material which has become property by application of human skill'; and $\$ 54(7)$, which excludes cell lines. This instantiates the Lockean standard in the new Act. For debates on what this may mean, see Moore v Regents of UCLA 793 P.2d 479 (Cal. 1990). 
'Kennewick Man' by the press, has filled many of these roles in the United States. Human skeletons - or any objects of cultural importance - are mutable in value, and thus in identity within regimes of regulation that turn on value. These issues were considered in depth by the Working Group on Human Remains in Museum Collections (WGHR), which was established by the Minister for the Arts, under the chairmanship of Professor Norman Palmer in May 2001. The WGHR highlighted not only the methods of acquisition of human remains, but also the underlying rationales for acquisition. The contrast they noted between human remains as cultural 'goods', logically residing in collections spurred and supported by a combination of scientific interest, curiosity, and interest in foreign cultural practices, and human remains as 'ancestors', and thus not appropriate subjects for collection and display, summarizes the ongoing debate regarding responsible behaviour vis-à-vis these remains. ${ }^{5}$

After two years of work and extensive consultations undertaken by the WGHR and the Department of Culture, Media and Sport (DCMS), 6 the Government incorporated the recommendations of the WGHR, in their mildest possible form, in Section 47 of the Human Tissue Act 2004. The WGHR concluded that Without discounting the possibility of other methods of sanctioning return, we believe that express relaxation of the British Museum Act 1963 would enable the relevant museums to return remains at their discretion without any concern that such return is contrary to law'. ${ }^{7}$ Under section $47(2)$, the British Museum, as well as other institutions in England, ${ }^{8}$ will have the right to repatriate or 'de-accession' any human remains in their collections that are less than 1000 years old. ${ }^{9}$ The right to de-accession in subsection (2) is extended to human remains mixed or bound with non-human materials in section 47(3), for

\footnotetext{
${ }^{5}$ Human Remains Report (2003), Chapter 3 'Origins and Destinations', et seq. This debate has not only informed the responses to the Consultation questionnaires that HRWG sent to many interested parties, but it has also served as the formulation of the issues as addressed in public on the issue of deaccessioning. In the professional scientific and curatorial arenas, and in the public arena as well, there seems to be a cautious preference in favour of retention rather than de-accessioning. See 'UK to Restitute Human Remains? Human Remains: Objects to study or ancestors to bury? Panel debate organized by the Institute of Ideas and the Royal College of Physicians' Anthropology Today 19(3) (2003) p. 28.

${ }_{6}^{6}$ DCMS had already published the Seventh Report of the House of Commons Select Committee on Culture, Media and Sport, Cultural Property: Return and Illicit Trade (July 2000), and it engaged in further consultation until and throughout 2004.

$7 \mathrm{n} 1$ above, $\$ 58$. In brief, the WGHR recommended that the government empower rather than mandate the return of human remains by removing the barrier to de-accessioning within the British Museum Act, and proposed a series of supporting procedures, including provision for dispute resolution between claimants and museums. It also recommended a national advisory panel under the auspices of DCMS; and a licensing system to regulate the management of human remains within museums.

8 The institutions named in Section 47(1) are: The Board of Trustees of the Armouries; The Trustees of the British Museum; The Trustees of the Imperial War Museum; The Board of Governors of the Museum of London; The Trustees of the National Maritime Museum; The Board of Trustees of the National Museums and Galleries on Merseyside; The Trustees of the Natural History Museum; The Board of Trustees of the Science Museum; and The Board of Trustees of the Victoria and Albert Museum.

9 'Any body to which this section applies may transfer from their collection any human remains which they 'reasonably believe to be remains of a person who died less than one thousand years' before the day on which this section comes into force if it appears to them to be appropriate to do so for any reason, whether or not relating to their other functions.' Human Tissue Act 2004 sec. 47(2).
} 
example masks that include human hair or a bark canoe that is sewn around infant bones. These institutions may either separate the human remains from the 'mixed' materials, or if that is impracticable, de-accession the entire object. Under the new regime, DCMS expects that the national institutions named in the Act will exercise their own judgment in regards to the questions that arise when determining when it is appropriate to de-accession human remains. However, these institutions will be accountable to the DCMS and the Arts Minister for the Code of Practice it adopts. In this way, the British Government splits the difference between the aggressive repatriation policy it has promised Australia, and which the WGHR supports, and the case-by-case, internally-managed approach favoured by the national institutions consulted.

The DCMS has now approved a Code of Practice intended to give guidance to institutions on repatriation. ${ }^{10}$ The British Museum has also drafted and approved its own policy on the matter. ${ }^{11}$ In light of the permissive language in Section 47(2) of the Human Tissue Act 2004, and the broad language in DCMS's Code of Practice, it is not surprising that the British Museum's policy charts a very narrow area in which the Trustees might permit repatriation claims to succeed. Although the language of the statute allows museums to repatriate human remains less than one thousand years old (thus attempting to avoiding repatriation claims for 'artefacts' such as mummified bodies or skeletons recovered from ancient grave sites ${ }^{12}$ ), the British Museum draws its lines even more narrowly, and it is worth quoting at some length:

The Trustees of the British Museum generally presume that the Museum's collection should remain intact for the benefit of present and future generations throughout the world, but they will give serious consideration to repatriating human remains that were buried or were intended for burial if

(a) they are less than 100 years old and a claim for their return is being made by a genealogical descendant; or

(b) they are less than 300 years old, and the claim is normally made by a source community which displays a cultural continuity with the remains in question, and the claim is made through a national government or national agency, and where, after taking any relevant independent advice... it is in their view likely that the cultural and religious importance of the human remains

\footnotetext{
${ }^{10}$ http://www.culture.gov.uk/NR/rdonlyres/0017476B-3B86-46F3-BAB3-11E5A5F7F0A1/0/Guidance HumanRemains 11 Oct.pdf $\#$ search $=\% 22 \mathrm{a} \% 20$ code $\% 20$ of $\% 20$ practice $\% 20$ for $\% 20$ the $\% 20$ care $\% 20$ of $\% 20$ historic $\% 20$ human $\% 20$ remains $\% 20$ in $\% 20$ museums $\% 20$ dcms $\% 22$

11 www.thebritishmuseum.ac.uk/corporate/guidance/BM_policy_on_human_remains.pdf

12 This language may simply be deferring conflicts regarding claims on ancient skeletons found in the UK or brought from abroad, and the UK Government may well have to address the issue again should a claim be brought.
} 
to the community making the claim outweighs any other public benefit.

The Trustees...regard ['mixed'] objects...as falling into a different category from human remains that were intended for burial, and so are unlikely to agree to any claim for their repatriation.

The Trustees...consider that claims are unlikely to be successful for any remains over 300 years old, and are highly unlikely to be considered for remains over 500 years old, except where a very close geographical, religious and cultural link can be demonstrated.

In addition, the policy specifies that claims must be made by governments on behalf of identified source communities and as a threshold, 'the claimant would have to establish a sound evidential base for a prima facie claim.' 13

This extremely defensive and conservative policy would seem to bring the 'debate' to a close, at least as concerns the British Museum. However, it is precisely at this point that the debate becomes interesting. The permissive language of the statute, and of the various Codes, neither forecloses nor gives clear direction in the resolution of any conflicts that may arise between a museum and a group requesting the return of these kinds of skeletons or artefacts. Indeed, the Natural History Museum is currently involved in mediating a dispute with the Tasmanian Aboriginal community about its intention to test human remains before repatriating them. ${ }^{14}$ The dispute centres on some of the same conflicts as in the Kennewick Man case in the US, discussed below. The competing claims of 'ancestry', 'science', display, and colonialism are not easily resolved, while opening the possibility of repatriation simultaneously brings the conflicts into the open. The following analysis attempts to consider the issues at stake in the repatriation of human skeletons, and to consider how the discourse of 'the commons' may intervene in resolving some of the ongoing conflicts in this area.

The world of cultural property analysis, particularly as regards the questions surrounding indigenous skeletons, remains radically open despite the attempts of lawyers, legislators, indigenous communities, and museum Trustees to fix it in a particular (legal or social) moment in time. Within this area of law, it becomes clear that 'ownership' is in some sense impossible, as the claimants look to claim history or identity as much as (or more than) the 'things themselves'. The conflation between human remains, property, and people (or personhood), means that the legal structures that order these kinds of cultural property disputes are themselves mutable in light of new developments in science or politics, or new discoveries by archaeologists or anthropologists. In this refractory and unstable condition, cultural property discourse reflects a set of profoundly modern functions and considerations. The existing methods of analysis turn on the

${ }^{13}$ www.thebritishmuseum.ac.uk/corporate/guidance/BM_policy_on_human_remains.pdf, p.5 
distinctions between 'cultural nationalism'15and 'cultural internationalism'16; as well as the distinctions between 'indigenous' and 'Western', and yet, these distinctions are constantly being challenged by the emergence of new kinds of identities, institutions, and commonalities. The British Museum's insistence on government requests, for example, might be very short-sighted. The repatriation request might attach to a 'new' discovery, which the Museum has yet to own or to contemplate; it might come from an interest group within the UK; or it might refer to a gift to the Museum which was, in turn, the result of dealings that would be considered illegal in the present climate. As in the current conflict between the Natural History Museum and the Tasmanian Aboriginal community, it may be the scientific testing of the remains before repatriation that creates competing 'ownership' claims. The standards that the DCMS Code of Practice, the WGHR Report, and even the various Museum policies espouse have to be examined. The law must determine the meaning of concepts such as 'genealogical descendant', 'cultural continuity' or 'very close geographical, religious and cultural link,' when the tools of 'cultural nationalism' and 'cultural internationalism' are themselves in flux. Numerous new conventions and pieces of domestic legislation attempt to ensure that the cultural connections between peoples and languages, practices, stories, landscapes, and all the other indicia of 'their' history and memory are maintained. The proliferation of cultural property laws and conventions continues, in part because 'history' becomes more valuable, not less so - and as that happens, the reach of statutes and claimants stretches increasingly further backwards. To take another example from the British Museum's policy, the idea that 'cultural continuity' cannot be proven if the human remains are more than 300 years old is disingenuous at best, and is already being challenged.

How then to think about this debate? The emerging discourses of the 'commons' might offer a new approach to problems of cultural appropriation. The ways in which communities constellate around questions of use, preservation, and common values, rather than more classical models of 'ownership', are the hallmarks of the commons debate. The statutory and regulatory schemes for repatriating human skeletons are the result of years of political action by indigenous communities, which face a dual set of problems: first, of identifying themselves as specific rights-bearers within the overarching categories of nationstates, citizens, or subjects more generally; and second, claiming communal ownership of skeletons or mixed objects that had been appropriated as 'historical artefacts' rather than as elements, and definitions of, particular communities. As this kind of political action becomes increasingly embodied in law, museums, on

\footnotetext{
14 http://www.eniar.org/news/repat61.html

15 'Cultural nationalism' is the position taken in the 1970 UNESCO Convention on the Means of Prohibiting and Preventing the Illicit Import, Export and Transfer of Ownership of Cultural Property, which the UK Government signed in May 2003.

16 'Cultural internationalism' is the position taken in the 1954 Hague Convention for the Protection of Cultural Property in the Event of Armed Conflict, which the UK Government is presently considering signing. The International Council of Museums (ICOM) and other international heritage organizations subscribe to this view.
} 
the other hand, propose increasingly sophisticated arguments for the retention of these kinds of objects. Between the poles of 'identity' and 'universality', 'commons' or 'commonality' might have a great deal to offer cultural property analysis. To expand on the themes that are implicit within the UK experience, it is worth looking at a situation in which a new discovery threw an almost-equally-new repatriation statute into disarray, as happened in the United States in series of events surrounding the discovery of Kennewick Man.

\section{COMMONS}

In an article applying commons discourse to the problem of illicit trafficking in cultural objects, Claudia Caruthers proposes that 'the commons' offers a set of insights/way of coping with the increasingly-inefficient conceptual framework of cultural property protection in this area. ${ }^{17}$ She argues that proliferating legislative protections, along the traditional lines given above, coexist with, and in fact may fuel, the increase in thefts and the ways in which cultural property is coming to resemble the drug and human trafficking markets. ${ }^{18}$ Legal solutions, no matter how extensive, are not managing to address this problem. Despite the various solutions proposed, there are ideological differences within the international community' that prevents UNESCO and other actors from ensuring that the solutions actually work. ${ }^{19}$ The differences, or disjuncts, that maintain the flood of black-market dealings in cultural property include the disparity in wealth between 'source' nations and nations where the goods transit and are ultimately sold; the differences in interpreting the goals and values that underlie the international instruments in this field; ${ }^{20}$ and the general difficulties in preventing highly lucrative illicit activity in any area of law enforcement.

Rather than focussing on the differences in values between different institutions and claimants, Caruthers begins by arguing that the problem is primarily economic and requires economic analysis. She proposes that cultural property be considered as a set of limited resources that can be analogised to 'the commons' in Garrett Hardin's essay 'The Tragedy of the Commons'. ${ }^{21}$ Her argument turns on the economic inequities that power the trade in cultural property and the modes of transmission of cultural property through illicit markets. ${ }^{22}$ She considers the (unsatisfactory) results if the market flow is managed under various economic models, finally turning to the effects of unregulated

${ }_{17}$ C. Caruthers, 'International Cultural Property: Another Tragedy of the Commons' (1998) 7 Pac. Rim L. \& Pol'y J. 143.

18 ibid, 158.

19 J. Warring, 'Underground Debates: The Fundamental Differences of Opinion that Thwart UNESCO's Progress in Fighting the Illicit Trade in Cultural Property' (2005) 19 Emory Int'l L. Rev. 227.

20 ibid, 178-9.

${ }^{21}$ G. Hardin, 'The Tragedy of the Commons' (1968) 162 Science 1243-1248.

22 n 17 above, 160-1. 
outright exploitation of cultural resources. There she finds 'a classic tragedy of the commons dilemma', where 'immediate relief of subsistence discomfort is purchased... with no consideration of its longitudinal effects on the people the remedy is to serve'. ${ }^{23}$ Here, she suggests that cultural property be viewed 'as a resource, not unlike a natural resource'. ${ }^{24}$

Thinking through the way in which commons discourse might be of use, she identifies the Lockean use-valorization at the heart of the distinction between the (legal) status of 'tenant-in-common', which is how Locke conceived the originary relationship between all people and the natural world, and the development of private property rights. 'Under Lockean analysis, competing rights are to be weighted according to the use the claimant makes of the disputed, hithertofore common, property. Ownership rights are to be bestowed on the claimant making the most aggressive use of the property resource'. ${ }^{25}$ However, she concludes that this form of property analysis does not map well onto cultural property disputes because it devolves into a 'value dualism implicating an adversarial ranking, a hierarchical model, in which one use/claim is super ordinate and the other use/claim subordinate. Given the significant polyvalence among factors at play with competing rights and claims, no such weighting is legitimately possible'. ${ }^{26}$ In this landscape, Hardin's proposed solutions - privatizing the resource, allocating the right to use the resource, aggregating all the parts of the resource and giving ownership or regulation rights to a central government, or mutually-agreed rigid regulation - all fail when applied to the illicit trafficking in cultural property. Quite simply, the tighter regulations that are supposed to follow increased scarcity do not seem to have purchase on the black market in cultural artefacts. ${ }^{27}$ Conflicting domestic import and export laws, auction houses and dealers all conspire knowingly or unknowingly to permit smuggling of artefacts and money laundering. Therefore, she concludes that the only solution is 'group cooperative schemes in which cooperation and compliance work together' will succeed in regulating these limited resources, and furthermore, that the principle that should control these schemes is 'moral restraint'. 28 The 'tragedy of the commons' in cultural property can only be resolved by 'norm-driven' models that 'employ a strategy of ethical imperatives and exhortations'. ${ }^{29}$ In fact, she turns to 'educative methods based on deontological ethics' in order to break down the incorrect perception that cultural property is alienable at all. ${ }^{30}$ She argues that if one takes the cultural dimension of cultural property seriously, then the thought of owning such an object becomes repulsive. As often happens in the commentary in the field, economics gives way to values.

23 ibid, 161

24 ibid, 161.

25 ibid, 162 .

26 ibid, 163

27 ibid, 166

28 ibid, 166.

29 ibid, 167.

30 ibid, 168 
As regards the inherent permeability of the art market to corruption, and the causes of this permeability, Caruthers may well be absolutely right. It is also clear that questions of value, and values, underpin most evaluations of 'culture', and therefore that any resolution of the problems in the field require solutions based in ethics as well as in regulation. However, there may be other reasons than the modalities of cultural property transmission that explain why the 'scarcity story' doesn't work in her analysis. Most fundamentally, cultural property is not an increasingly-scarce resource. Quite the reverse, as the plethora of new museums, new Governmental initiatives, and new pieces of legislation (national and international) identifying new and different pieces of information, life experiences, landscapes, and objects as 'cultural property' show. ${ }^{31}$ Against this backdrop, it is reasonable that analyses based on increasing scarcity might fail. Yet, scarcity is only part of the story in arguments from within the discourse of the commons. The other parts are the concepts of appropriation, and of value/values. If one looks at the discourse from these perspectives, the question of how 'the commons' may affect, or be applied to, cultural property analysis resolves itself differently. In terms of methods and meanings of appropriation, cultural property and heritage, as objects and as sets of rights, conceptually sit somewhere between land-based rights and knowledge-based rights. 'Appropriation' in this context is complex, but in general the law valorizes the Lockean formulation of 'labour-mixing' as the means by which rights are obtained. In terms of values, again the analysis is complex, but it may also yield to commons theory. One could say that the values at play span the extremes of the purely natural and the purely conceptual (as for example, in indigenous skeletons in museums), as objects that are cultural property (or sites and practices that are heritage) combine the values inherent in the ownership of both land and knowledge. The values that animate cultural property discourses, in gross, turn on preserving, maintaining, and at times, creating, cultural identification and communal identity against the backdrop of shifting national and international boundaries and interests. This raises the question of commonality generally, and proposes that cultural property analysis, like intellectual property analysis ${ }^{32}$, occurs on a field of endlessly-shifting and reforming 'commons'.

More finely, the values at play in cultural property discourses are very similar, if not the same, as those at play in the discussions of 'the commons' in the areas of

31 See, for example, the 1995 UNIDROIT Convention; the Dealing in Cultural Objects (Offences) Act 2003; www.culturalcommons.org; the 2003 UNESCO Convention for the Safeguarding of the Intangible Cultural Heritage (http://www.unesco.org/culture/ich_convention/index.php).

32 In the area of intellectual property law, the term 'cultural commons' has been developed by commentators and practitioners to mean the set of cultural goods (words, images, stories, and sounds) which are in the public domain, and which are considered to be open and accessible to all, in the sense of being available as a substrate for further economic and cultural uses. In this area, the concept of 'the commons' is used to thematize the point of the conflicts that arise between those who claim that certain material is 'in the public domain', and the legal and market-based entitlements of trademark holders and other authors or producers of intellectual property whose material is being used. Property, publicity, and monopoly rights are contrasted with the idea of a 'cultural commons', or a realm of cultural goods in which access and use rights are largely unrestricted. Of course, any notion of an unrestricted domain created by technology or broadly-based media promulgation of cultural goods is in itself utopian or anarchistic or both. See: Lawrence Lessig, Code. 
land/environmental law and intellectual property: preserving and expanding knowledge, communal identity, and the opportunity for future use(s) and developments. Participants in the debates regarding 'the commons' in environmental law, intellectual property, and arguably cultural property as well, are establishing (and then policing) the thresholds and boundaries between differing versions and visions of the past, of 'us' and 'them', and of what is available to be claimed for use, and by whom. In this sense, there is a second or other reading of 'the commons' and what it may mean that arises from the work of John Locke and Garrett Hardin. In order to consider the repatriation debate in this context more specifically, it is worth briefly discussing two points: first, the meaning of 'the commons', as originally put forth by John Locke in 1690, and then picked up and reworked by Garrett Hardin in 1968; and second, the definition of the commons as, in fact, common values.

In Chapter V of the Second Treatise of Government, 'Of Property', Locke writes 'Whether we consider natural reason,... or revelation,... it is very clear, that God...has given the earth to the children of men; given it to mankind in common'. ${ }^{33}$ Reason (also given us by God) tells us that the earth and its fruits are given to man in common for our preservation, comfort, and convenience. This is the original moment of the 'state of nature', or the very beginning of the pre-private-property moment postulated by Locke. Humans all share in the earth as 'tenants-in-common', that is, in undivided shares. Locke argues that private property rights can arise nonetheless from this grant of the earth in common. ${ }^{34}$ The things of nature, 'being given for the use of men, there must of necessity be a means to appropriate them some way or other, before they can be any of any use, or at all beneficial to any particular man'. ${ }^{35}$ From the originary grant of the world, use and appropriation are the logical - and required - steps in order to make the things of nature beneficial (as food or shelter) to humanity. The emphasis on appropriating leads Locke to his next point. Even though man has no property in the earth and its creatures, he does have property in his own person: 'The labour of his body, and the work of his hands... are properly his. Whatsoever then he removes out of the state that nature hath provided...he hath mixed his labour with, and joined to it something that is his own, and thereby makes it his property'. ${ }^{36}$ Locke then postulates anti-waste and anti-spoilage provisions as limitations on the right to amass private property. ${ }^{37}$ While still in the state of nature, however, Locke imagined that people developed money - and here the limitations on labour, waste, and spoilage ceased to operate, as money does not spoil, it creates more goods for others (and thus removes the need to leave as much and as good in kind, as previously), and through buying and selling labour, it allows unlimited appropriation, as the labour of one's employees

33 J. Locke, 'Of Property' in Second Treatise of Government Edited, with an Introduction by C.B. Macpherson (1690, Indianapolis: Hackett Publishing Company, 1980) \$25, emphasis in the original.

${ }^{34}$ C. B. Macpherson, The Political Theory of Possessive Individualism, Hobbes to Locke (Oxford: the Clarendon Press, 1962).

$35 \mathrm{n} 33$ above, $\$ 26$, emphasis in the original.

$36 \mathrm{ibid}, \$ 27$, emphasis in the original.

37 ibid, SS 27, 30, 31 et seq. 
belongs to the employer and fixes the employer's property in the things taken out of the commons. ${ }^{38}$ This occurs before men enter into civil society, which is formed fundamentally to protect the private property that they have acquired. Therefore, use by man defines the purpose of the commons and furthermore, that use is seen by Locke as naturally unrestrained or unlimited. Man is 'naturally infinitely desirous'; in Locke's scheme the purpose of government is not to safeguard 'the commons', but to protect the unequal distribution of the property acquired. ${ }^{39}$ Yet, the commons cannot go unused or unappropriated either. If the commons are not used, then they are wasted and humanity dies for lack of sustenance. The result of this is to place use and labour at the centre of value creation, and to make labour give rise to property.

This understanding of labour, used to secure property rights in land as well as in intellectual property, has never been entirely uncontroversial. ${ }^{40}$ The values of the 'agrarian ideal' and the definitions of authorship cannot be taken for granted in the modern world (and possibly, they should never have been allowed to remain unquestioned). ${ }^{41}$ At its core, however, is the act of appropriation, the reaching across the boundary of what is 'in common', and 'mixing labour' with the thing desired. It is this gesture that gives rise to the more interesting questions about the commons and cultural property. First, after the original moment of a limitless natural world in which ownership was unproblematic, the question of how 'the commons' are defined became paramount - who decides the boundary-line? Second, also after this moment, the act of appropriation became managed by the exchanges of labour, and money, formalized by contract, debt, investment, and other forms of legal and financial regulation, as well as by the legal investitures of previous appropriators - through use - as present owners. However, the idea of the commons and the idea of use were inextricably linked from the beginning, and remain so. In cultural property analysis, we can see this relationship articulated in reverse' so to speak. The idea of use, based in the need for ethnic, religious, or cultural survival, can define an object as being 'in the commons'. For example, indigenous skeletons in a museum, which can be defined as a 'commons' in a series of tenuous or metaphorical ways, but which legally is usually some form of trust established within a private institution, or a public institution (also usually in the form of a trust) created by statute, can be appropriated using the same arguments as would be made if the skeletons were found in an unowned wilderness in the state of nature. The fact that they have been 'taken' at least once does not stop new claimants from attempting to take them again; they are defined by their necessity for the (cultural) survival or nourishment of specific groups. At the moment that their present 'ownership' stops being a barrier to the attempt to repatriate the skeletons (or the objects), they have moved from the world of property rights back into the 'state of nature': 'The fruit, or venison, which nourishes the wild

38 ibid, $\$ 28$.

39 Macpherson, in ibid, xviii.

${ }^{40}$ Lizzie Cooke, The New Law of Land Registration (Oxford and Portland, Oregon: Hart, 2003).

41 Macpherson, in $n 33$ above, xviii-xx. 
Indian, who knows no inclosure, and is still a tenant in common, must be his, and so his, i.e. a part of him, that another can no longer have any right to it, before it can do him any good for the support of his life'. ${ }^{42}$ The notion of 'so his, i.e. a part of him, that another can no longer have any right to it' is crucial to the notion of 'the commons' as there are certain objects that must be appropriated in order to become useful: food and land, according to Locke, and also, in today's world, culture. Deciding that any of these objects may be acquired as of right brings the user into the realm in which arguments about the commons can be comprehended.

Skeletons in museums, or other elements of cultural property, may also be retained on arguments that seek to redraw the boundaries of the commons. In 2002, more than thirty of the world's great museums, including the five most prestigious, ${ }^{43}$ signed a declaration stating that they were 'universal' museums. According to Mark O'Neill, Head of Glasgow Museums, this was a strategy to defend against repatriation claims. ${ }^{44}$ Without disapproving of the concept of universal museums, O'Neill points out that to be truly 'universal', the great museums would have to give up the curatorial position that he calls 'the sense of being the invisible centre', and which makes itself heard in the exclusion of voices and perspectives other than the curators' from the exhibits. ${ }^{45}$ Speaking for the entire world, as 'universal' museums claim to do, is also an act of appropriation: these museums claim the authority to present and authorize the history, identity, and value(s) of the artefacts and peoples represented within their collections. In this schema, the categories of 'nationalism' and 'internationalism', which do not protect the museums from repatriation claims, are tipped into the category of 'universality', which does. Are modern museums claiming to be an iteration of 'the commons' in order to move away from histories of elitism and colonialism, and then using limited access regimes and the rhetoric of communal values in order to protect their collections? In one sense, this is too big a question for the present analysis, as over the past twenty years at least the roles and definitions of museums have been in a state of tremendous expansion, and, in regards to the repatriation debate, to some sharp contractions as well. In another sense, however, this question exposes the problems of thinking about 'the commons' at all. What constitutes the commons in this realm? Is it a matter of the project of the museum, the collection, or the audience? ${ }^{46}$ In terms of cultural property, museums play different roles as acquirers, protectors, members of the art-market complex, and institutions that police the cultural identity politics implicit in repatriation claims. In each role, they represent a different iteration of the landscape of a

\footnotetext{
$42 \mathrm{ibid}, \$ 26$, emphasis in the original.

${ }_{43}$ These are: the Hermitage (St. Petersburg), the Metropolitan Museum (New York), the Berlin State Museum, the British Museum and the Louvre.

${ }_{44}$ M. O’Neill, 'Enlightenment museums: universal or merely global?’ (2004) 2(3) museum and society 190202 (Nov).

45 ibid, 198.

${ }^{46}$ F. McLean, 'Museums and National Identity' guest editorial in special issue on museums and national identity, (2005) 3(1) museum and society 1.
} 
possible commons, and in each, they are on one or the other side of the appropriative gesture that signifies the presence or absence of an argument regarding commonality.

Locke's emphasis on appropriation is echoed by Hardin's. In the unproblematized (and often fictionalized) past moment ${ }^{47}$, the conflicts that make up the debate regarding access to or use of 'the commons' - here, many of the debates surrounding the ownership of cultural property - are implicit rather than explicit, dependent upon the advent of historical events such as invasion, colonization, or destruction on the one hand, and agricultural, social and economic differentiation on the other, in order to become visible. ${ }^{48}$ However, in 1968, Garrett Hardin's argument in 'The Tragedy of the Commons'49 portrayed the inevitable derogations from the original (if purely rhetorical) 'state of nature' in which survival goods are shared and preserved in some kind of natural communal harmony. Without postulating any sort of cultural disturbance or economic imperative, Hardin showed that 'the commons' as an unregulated free set of resources open to use by all cannot exist; in fact, that conflict and acquisitiveness are as much at the heart of communal appropriation of resources in the present day as they were in Locke's. Postulating both social stability and that each member of the society is a rational being seeking to maximize his gain, he shows that each person, when acting rationally in their own self-interests, will contribute to the inevitable exhaustion of the natural resources that support them. Interestingly, Hardin, like Locke, puts appropriation and greed (or at least, desire) at the centre of his discussion of commonality, but where Locke is sanguine about the effects, Hardin, thinking about present-days problems such as over-grazing, over-fishing, pollution and population control, concludes that 'Freedom in a commons brings ruin to all.' Therefore, he looks to property and coercive management or taxation regimes to protect 'the commons' from us, or to protect us from destroying the commons. Like in Locke, one kind of taking often becomes another: the lines of what is, or can be, commonly used and accessed are redrawn according to physical, economic and cultural necessity.

The discourse of the commons, therefore, has a bifurcation at its centre: as it postulates a 'commons', it also demonstrates the impossibility thereof. This tension has animated the commons discourse in environmental law, and more recently in the field of intellectual property. Within the domain of cultural property, however, this duality exists in a less problematic fashion. Acquisitiveness has always served as the engine of cultural property disputes and debates, and preservation has been one of the prime arguments for justifying the transfer or

${ }^{47}$ Locke's description of how one would use an original 'commons' might well be seen as similar to the descriptions of uncomplicated communal participation in a particular culture, or the unproblematic access to and use of culturally significant objects or landscapes in the recent past postulated by Caruthers.

${ }^{48}$ To a great extent, such a description is an iteration of the Lockean 'state of nature', and thus a fictional and purposive depiction of communal interaction - but this Lockean notion of an originary and uncomplicated participation in, and partaking of, a set of goods in central to the project of thinking 'the commons.'

${ }^{49}$ G. Hardin, 'The Tragedy of the Commons' (1968) 162 Science 1243-1248. 
retention of the cultural property. Furthermore, the more that theorists and commentators look for the definitions of culture, community, and commonality that would aid in resource allocation in this area, the more the criteria are shown to be very fluid. As such the question arises: Do we talk about 'the commons' as a means not of protecting, but of legitimating the taking of resources? Reading Locke and Hardin together, a congruence emerges between 'protecting' and 'taking', a congruence that is often seen in the arguments made by museums, dealers, collectors, special interest groups, indigenous peoples, academics, auction houses, curators, looters, and others regarding the ownership, (in)alienability, or repatriation of cultural property. For these actors, as for Hardin, the discourse of protection, or of survival, serves just as well as that of contested ownership as a means of making cultural resources available to other, often newly-articulate, 'owners' or users. The commons, as a discourse, thus may function as a strategy in longer-terms plans of acquisition.

The problem of thinking about the use of 'the commons' as a strategy of acquisition requires thinking about how the shifting boundaries of the commons are drawn and redrawn, and which values animate and justify the specific appropriations. Hardin refers to the problems of drawing boundaries around 'the commons', or the problems of regulating use and access in regards to them, in total, by reference to 'a not generally recognized principle of morality, namely: the morality of an act is a function of the state of the system at the time it is performed.' Shifts in morality, therefore, would lead to shifts in what constitutes the commons. This is very obvious in cultural property analysis generally, and especially obvious in the debates regarding repatriation of skeletons. The disputes that arise regarding cultural property are all too often within the class that Hardin names 'no technical solution problems', i.e., one where legal rules and regulations cannot fully address the 'change in human values or ideas of morality' - except, as he points out, if one looks at the matter from the point of view of survival needs. Then it becomes easier to navigate the polyvalent and shifting landscape of legitimate appropriation and (common?) values. Hardin's argument about boundaries, values, and survival is visible in the case of Kennewick Man, the debate over the 'ownership' of a 9,000-year-old skeleton discovered in the United States, which also demonstrates some of the issues currently being mediated between the Natural History Museum and the Tasmanian Aboriginal community in London today. These conflicts demonstrate the impossibility of avoiding heritage conflict, or the conflict between indigenous communities and scientists and curators, through the promulgation of law. Instead, the question of commonality is at the core of the repatriation debate, and requires careful analysis of what constitutes common values in a given culture. 


\section{KENNEWICK MAN}

The case that would pit scientists against a coalition of Native American tribes and prompt a resurgence of the debate about indigeneity, race, and cultural heritage in America began in July 1996, when a skeleton was discovered on the bank of the Columbia River by two college students. They notified the police, who then called in the County coroner. The coroner asked an area anthropologist, James Chatters, to investigate. ${ }^{50}$ Chatters's findings were initially that the skeleton was Caucasian. ${ }^{51}$ The definitions of 'Caucasoid' and 'Caucasian' do not dovetail exactly: 'Caucasian' is a 'culturally defined racial category', ${ }^{52}$ whereas 'Caucasoid' is 'a term of art that characterizes the descendants and early inhabitants of a broad set of regions, including both Europe and parts of South Asia. American Indians have features more in common with Mongoloid peoples descended from North Asia'. ${ }^{53}$ The usage between the terms and traits of Caucasoid/Caucasian is sufficiently elided for Chatters '[a]t that point, [to be] quoted as saying in The New York Times, 'I've got a white guy with a stone point in him....that's pretty exciting. I thought we had a pioneer'. ${ }^{54}$ However, the stone point was found to be from the 'Cascade period', dating the remains to about 9,000 years ago. This was shocking; the age and race of the skeleton became immediately at issue in America. The effect was to reopen the question of 'true' or 'original' ownership of the early history of North America. Among other issues, ownership of the skeletal remains metonymically stood for ownership of the moral high ground regarding the Native American claims of settler land-theft.

The United States Federal statute that controls disposition of these bones is the Native American Graves Protection and Repatriation Act (NAGPRA), which became law in 1990.55 Unlike the Human Tissue Act 2004, NAGPRA tightly and prescriptively controls the ownership and disposal of Native American human remains, and sacred or cultural objects, presently in federally-funded museums, or found on Indian or federal land. As soon as the radiocarbon dating confirmed the age of the remains, conflict erupted as to their ownership and identity. The coalition of Indian tribes, unofficially led by the Umatilla Tribe, claimed the skeleton under NAGPRA. The coalition insisted on its right to rebury the skeleton immediately in a secret location. It would allow no (further) testing. This outraged the forensic anthropologists and other scientists working on theories of the 'peopling' of America. In order to preserve the skeleton as an object of study, this community claimed that the Caucasoid features and the remarkable age of the skeleton were reasons for not applying NAGPRA in this case. The result was a

50 R.W Lannan, 'Anthropology and Restless Spirits: The Native American Graves Protection and Repatriation Act, and the Unresolved Issues of Prehistoric Human Remains' (1998) 22 Harvard. Environmental Law Review 369. Distinguishing recent remains from those in Indian burial sites was a familiar problem in that area of Washington.

51 A.L. Slayman, 'A Battle over Bones' 1997 50(1) Archaeology January/February 16.

52 D. Preston, 'The Lost Man', The New Yorker, 16 July (1997), 70.

53 n 49 above, 374.

${ }^{54}$ n 50 above, 16.

55 Native American Graves Protection and Repatriation Act (1990) 25 U.S.C. $\iint$ 3001-13. 
lawsuit. The plaintiffs in the case, Bonnichsen $\mathrm{v}$ United States, 56 included two Smithsonian Institution anthropologists and six prominent professors of anthropology. The complaint alleged that Kennewick Man was a rare discovery of international as well as national importance. Study of the skeleton would yield invaluable information regarding the history of the Americas and of human evolution more broadly. As a result, repatriation would result in 'irreparable harm' to science. ${ }^{57}$

As of August 2002, the District Court issued three orders in the case. The first, in February 1997, held that the Court had jurisdiction to review the Corps' decision that the remains found were Native American and thus came within the ambit of NAGPRA. In the second, issued June 1997, the Court denied a summary judgment motion by the Corps and simultaneously denied a motion by the scientists for permission to study the remains. In addition, it held that all the parties in the case have standing to bring actions under NAGPRA. Most importantly, U.S. Magistrate John Jelderks "asked lawyers for both sides to prepare arguments as to the meaning of 'indigenous' under NAGPRA". 58 In January 2000, the United States Department of the Interior (DOI) concluded that the remains are 'Native American' within the meaning of the statute. In September 2000, after considering approximately 25,000 pages of evidence, and indeed conducting further tests on the remains, the DOI concluded that a preponderance of the evidence shows that the Kennewick remains are culturally affiliated with the present-day Indian claimants. On the basis of that determination, the Secretary directed repatriation. The plaintiffs in Bonnichsen v United States then filed an amended complaint, and moved to have the DOI's disposition decision vacated. On August 30, 2002 Judge Jelderks reversed the decision of the Secretary.

For purposes of the present analysis, the case of Kennewick Man presents several points of interest. First, it demonstrates how a statute barely six years old, and the result of years of lobbying and debate in the US legislative system, can be thrown into disarray by a new archaeological discovery. In this sense, it also demonstrates the 'open world' character of cultural property, and its similarity to other forms of 'cultural commons.' Second, it demonstrates the contestability of definitions such as those proposed by the WGHR and used in the DCMS Code of Practice and the British Museum's repatriation policy document. Finally, it highlights the problems of working with the notion of the 'commons' or common values, unless one is willing to imagine the appropriative instinct, or arc, as foundational to the shaping of this landscape. The DCMS Code of Practice defines 'cultural community' 59 and 'genealogical descendants' 60 broadly. It

\footnotetext{
56 At 969 F. Supp. 614 [D. Or. Feb. 19, 1997]; 969 F. Supp. 628 [D. Or. June 27, 1997].

${ }^{57} \mathrm{n} 49$ above, 379.

${ }^{58}$ D.W. Ackerman, 'Kennewick Man: The Meaning of 'Cultural Affiliation' and 'Major Scientific Benefit' in the Native American Graves Protection and Repatriation Act' (1997) 33 Tulsa Law Journal 359, 364.

59 'A group of people who identify themselves as being a cultural group through a shared sense of identity.'
} 
foresees that 'Ancient human remains without living cultural descendants' will not be either requested from museums or returned if requested. However, 'human remains with cultural descendants' and 'recent human remains with genealogical descendants' would present claims that might be controversial or problematic. The British Museum policy states only that 'cultural continuity' and age of remains form the substantive thresholds that will trigger consideration under their repatriation policy. To some extent, this is very good practice, as the more an institution defines its terms in this area, the more it gives up its discretion to respond to claims and challenges as it sees fit. However, even the broadest of definitions cannot escape challenge in situations where claims are made. In the case of Kennewick Man, the mere appearance of the skeleton required not only statutory interpretation and the promulgation of new regulations, but also a series of decisions about what constituted evidence of 'cultural continuity.' Kennewick Man might well serve as a cautionary example for the approach of the UK government and the British Museum if they are confronted with a similar claim. The notion that 'ownership' of such an ancient skeleton will not be contested may not be taken for granted. Unlike the Human Tissue Act 2004, NAGPRA is typical of the emerging statutory instruments meant to repatriate objects and reinstate rights based on cultural claims. ${ }^{61}$

Under NAGPRA, the relevant questions of statutory interpretation raised by Bonnichsen $\mathrm{v}$ United States were questions turning on 'commonality', i.e. whether the skeleton was 'Native American' under the Act, and 'how much evidence of "cultural affiliation" there must be for claimaint tribes to be given "ownership or control" of them'. ${ }^{62}$ The definition of 'Native American' in NAGPRA 'concerns not ...[an] individual's origin, but whether his "tribe, people, or culture" was itself "indigenous" to the United States'. ${ }^{63}$ The collective must be 'indigenous'. The archaeological and anthropological theories of the peopling of America suppose that the first inhabitants of the continent came from elsewhere. The question then becomes, when did indigeneity begin, or at least, when did it begin within the terms of NAGPRA? The claimants in this case argued that the skeleton is too old to be linked to lineal descendants, was not discovered on tribal land, and the federal land on which it was discovered had not been recognized by a final judgment of the Indian Claims Commission or a United States Court of Federal Claims as the aboriginal land of any tribe. Thus, the question regarding 'ownership and control' had to be determined under evidence that establishes an identifiable earlier group, which includes evidence of group identity and cultural characteristics, distinct patterns of material culture manufacture and distribution

\footnotetext{
60 'Biological, social and adoptive kin or family. Persons who define themselves by a demonstrable social or biological relation to the deceased that they adopt as a form of kinship. The tie may be demonstrated through birth, marriage, adoption, family membership, or some other arrangement through which the parties share a close identity of kinship kind, either within or across generation.

${ }^{61}$ For example, the same standards are used in the Australian Native Title Act.

62 n 49 above, 400 .

63 n 49 above, 401 .
} 
methods, and a biologically distinct population. The evidentiary standard for establishing shared group identity is that the link must be 'reasonably' traceable.

To what extent is this relevant to the UK repatriation debate and to 'the commons'? The lack of a dedicated repatriation statute in the UK seems to avoid the complexities of political and legal interpretations that other countries have faced. However, these kinds of questions and terminology underlie the reality of repatriation claims generally and are profitably understood as part of the discourse of the commons. 'Indigeneity' is an ongoing discussion about common values and common identity, and a strategy for ownership claims. Most importantly, the reams of documents and years of work that went into determining whether Kennewick Man was a 'Native' American for purposes of NAGPRA occurred against the backdrop of a contentious public debate in America about what constitutes a 'Native American' more generally. Here, the questions of commonality, understood as the problem of values defining originary national identity and land rights, once again attach to Hardin's formulation of value(s) in 'the commons.' The question posed by Douglas Preston in The New Yorker, 'What was a Caucasoid man doing in the New World more than ninety-three centuries ago?' resonates, therefore, in several different spheres of possible analysis. The question itself already points to the sorts of sociological, scientific and historical judgments that are being challenged and defended in the commentaries on these kinds of cases. To some extent, the question in itself supports the patently false proposition that knowledge about race and habitation in America was, until now, uncontroversial. A skeleton calls forth the history of the skin and its sustenance: a history that is both disputed and ineffable. In the realms of law, science, and the media, the bones were fleshed and put into motion. 'Kennewick Man's' appearance as a controversy within the national consciousness must be assessed as a function of the ongoing debates regarding science, culture, and legitimate ownership of history.

Therefore, in allocating ownership of any contested bones, the field on which disputes occur is organized by the values that define national consciousness along moral and historical lines. For example, as regards Kennewick Man, arguably, the foundational concerns of American self-consciousness are progress and identity. From the perspective of the dominant culture, an American (of any origin) is a person who makes progress the hallmark of their identity. A non-American is a person who chooses identity over progress. A 'Native' American is the repository, in the story that Americans tell of their history, of the conflict and fluctuations between these two poles. ${ }^{64}$ The debate over the meaning of 'indigenous' does not constitute a reappropriation of Native American identity, therefore, but an appropriation of it. The links between 'Native' and 'savage', and 'science' and 'progress', reference colonialism, and Hardin's formulation of moral judgment. The conflicts and congruences listed above move across and through the history of colonization. 'Progress' or 'Native' reach their apogee as descriptive terms against the personhood, however defined (bodies and minds, but also query 
'souls'), of the colonized. ${ }^{65}$ In this realm, ancient bones take many positions. The bones become a totem; as they are unfleshed, they can be made to wear skins of different colours. When they are gathered up, studied, identified, they constitute a kind of kaleidoscope of identity and political and scientific necessity. If at issue is decolonization, which is always more or less at issue in debates regarding the repatriation of indigenous skeletons, then what must be addressed is what Fanon refers to as "the replacing of certain "species" of men by another "species" of men'. ${ }^{66}$

\section{CONCLUSION}

In this redrawing of boundaries through competing claims of appropriation linguistic and cultural as well as bones and land - the practices and purposes of 'the commons' become visible. An ancient skeleton found in the UK and claimed by a particular group, for example, may well plunge the UK into the dilemmas of defining common values across contested cultural histories. In the beginning, therefore, 'All the World was America...', as Locke writes, but that originary moment repeats infinitely in each claim to an ancient skeleton or a new technology or piece of information. Here, 'the commons' may find its purpose in cultural property analysis. The appearance and disappearance of specific commons in the legal realm, as well as in the public consciousness, should be understood as the mapping of the appropriative instinct roaming through a landscape made up of overlapping if not infinite resources. Commons appear and disappear according to emerging objects, economies, and normative imperatives. The deployment of 'the commons' is always as a strategy for returning already-owned-things (experiences, cultural events, skeletons, or quasi-objectifiable artifacts) to an acquirable state. Although protection of resources is the stated goal of many claimants to scarce or valuable resources, taking is at issue in these discourses, and the example of cultural property, which also participates in the theorization of commonality and communality in the realm of property law, makes this visible.

${ }^{64}$ T. Flessas, PhD thesis 'The Ownership of Time: Culture, Property and Social Theory' (University of London Library, 2003).

${ }^{65}$ M. Foucault, Discipline and Punish: The Birth of the Prison, Translated by Alan Sheridan (London: Penguin Books, 1977).

${ }^{66}$ F. Fanon, The Wretched of the Earth, Preface by Jean-Paul Sartre, Translated Constance Farrington (New York: Grove Press, 1963), 35. 